\title{
First evidence of a tetrapod footprint from the Triassic of northern Victoria Land, Antarctica
}

\author{
Thomas Mörs ${ }^{1}$, Grzegorz Niedźwiedzki², Laura Crispini ${ }^{3}$, Andreas Läufer ${ }^{4}$ \& Benjamin Bomfleur ${ }^{5}$ \\ 1 Department of Palaeobiology, Swedish Museum of Natural History, Stockholm, Sweden; \\ ${ }^{2}$ Subdepartment of Evolution and Development, Department of Organismal Biology, Uppsala University, Uppsala, Sweden \\ ${ }^{3}$ Dipartimento di Scienze della Terra, Ambiente e Vita, University of Genova, Genoa, Italy; \\ ${ }^{4}$ Federal Institute for Geosciences and Natural Resources (BGR), Hannover, Germany; \\ ${ }^{5}$ Palaeobotany Research Group, Institut für Geologie und Paläontologie, Westfälische Wilhelms-Universität Münster, Münster, Germany
}

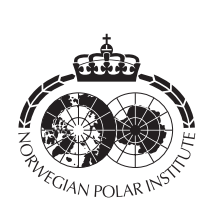

\begin{abstract}
Here, we report on a tetrapod footprint from the Transantarctic Basin in the far north of Victoria Land, which marks the first record of terrestrial vertebrates for this region. The single specimen derives from a previously unknown lithological unit of Middle or Late Triassic age of the Beacon Supergroup in the Helliwell Hills in the central Rennick Glacier area. It differs in both size and morphology clearly from Middle Triassic trackway types from the upper Fremouw Formation of the Queen Alexandra Range in southern Victoria Land, and likely represents a primitive amniote, procolophonid or therapsid. The footprint is the third evidence of fossil vertebrate trackways in Antarctica.
\end{abstract}

\section{Keywords}

Beacon Supergroup; Helliwell Hills; ichnotaxon; Procolophonichnium; Rennick Glacier; Transantarctic Basin

\section{Correspondence}

Thomas Mörs, Department of Palaeobiology, Swedish Museum of Natural History, P.O. Box 50007, SE-104 05 Stockholm, Sweden. E-mail: thomas.moers@nrm.se

\section{Introduction}

Since the first terrestrial tetrapod fossil was described from the central Transantarctic Mountains in Antarctica (Barrett et al. 1968), three distinct early Mesozoic tetrapod faunas have been recognized from the lower Fremouw Formation (Lower Triassic), the upper Fremouw Formation (lower Middle Triassic) and the Hanson Formation (Lower Jurassic) (Smith 2013). In addition, a few tetrapod specimens are known from the Lashly Formation (Upper Triassic) in southern Victoria Land (Hammer et al. 2004). Most of the early Mesozoic Antarctic tetrapods, that is, temnospondyl amphibians, therapsids, archosauromorphs, pterosaurs and dinosaurs, are documented by body fossils, that is, skulls, jaws, teeth, bones and even entire skeletons (Smith et al. 2011; Stilwell $\delta$ Long 2011; Smith 2013). Tetrapod trace fossils have also been found in the central Transantarctic Mountains: burrows of therapsids and parareptiles have been found in the lower Fremouw Formation in the Beardmore Glacier region (Miller et al. 2001; Sidor et al. 2008) and trackways, perhaps made by the therapsid Lystrosaurus, have been discovered in the upper Fremouw Formation of the Queen Alexandra Range (Macdonald et al. 1991). Together with avian tracks from the Eocene Fossil Hill Formation at Fildes Peninsula on King George Island, South Shetland Islands (Covacevich \& Rich 1982; Mansilla et al. 2012), these were the only known vertebrate trace fossils from Antarctica.

Here, we describe an isolated tetrapod footprint from the Transantarctic Basin in the far north of Victoria Land, which represents the first evidence of terrestrial vertebrates for this region. Our specimen derives from a previously unknown lithological unit of the Beacon Supergroup in the northern Helliwell Hills in the central Rennick Glacier area (Fig. 1). The unit has a thickness of $250+m$ and consists of greenish-weathering, fine-grained sandstone and thick overbank mudstone with thin coal seams, locally containing abundant silicified wood, silicified peat and occasional occurrences of plant compressions. The occurrences of Kykloxylon, Agathoxylon, Heidiphyllum and Lepacyclotes indicate a Middle or Late Triassic age (Bomfleur \& Mörs 2016; Bomfleur et al. 2018). 

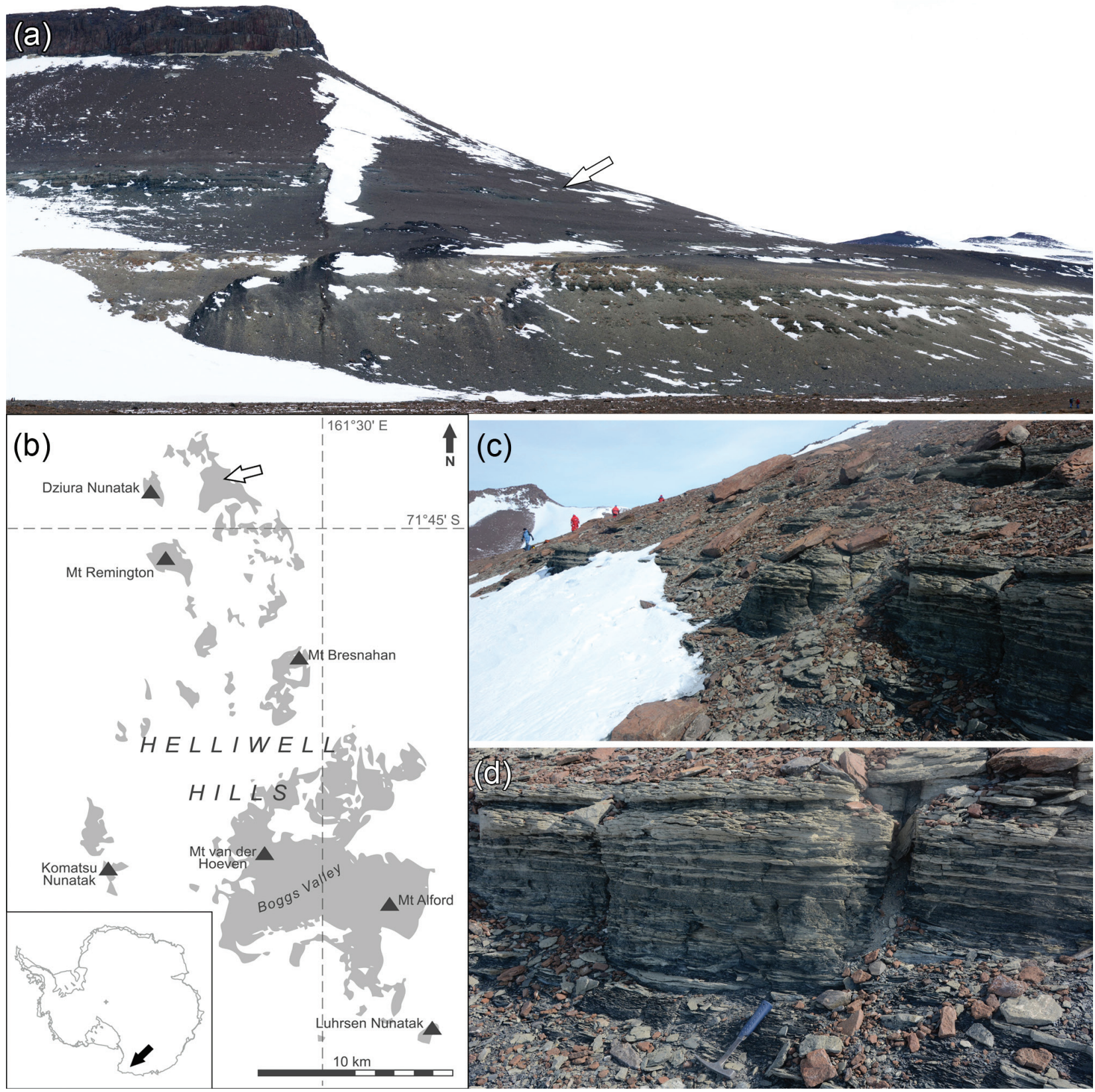

Fig 1 (a) Location of the fossil locality on the north-west slope of an unnamed mesa in the northern Helliwell Hills (white arrow). (b) Map of the Helliwell Hills with the fossil locality at the Helliwell Hills Camp (white arrow) and of the Helliwell Hills in Antarctica (inset, black arrow). (c) Fossil locality with exposed Triassic sediments. (d) Close-up showing the greenish-weathered, fine-grained sandstone and mudstone layers, hammer for scale. (Photos by B. Bomfleur.)

\section{Material and methods}

The specimen described here was collected by some of the authors (TM, LC, AL and BB) during the 11 th German Antarctic North Victoria Land Expedition (GANOVEX XI) in the austral summer of 2015/16. This specimen was found while surface collecting in the active layer on the north-west slope of an unnamed mesa in the northern Helliwell Hills, close to the field camp, GPS data $71^{\circ} 43.844$ 'S, $161^{\circ} 21.413^{\prime} \mathrm{E}$ (Fig. 1). The specimen is preserved as a cast in a light-coloured, finegrained sandstone slab of ca. $3 \mathrm{~cm}$ thickness. It was mechanically cleansed, documented photographically and cast.

The specimen is housed in the polar sample collections of the Federal Institute for Geosciences and Natural 

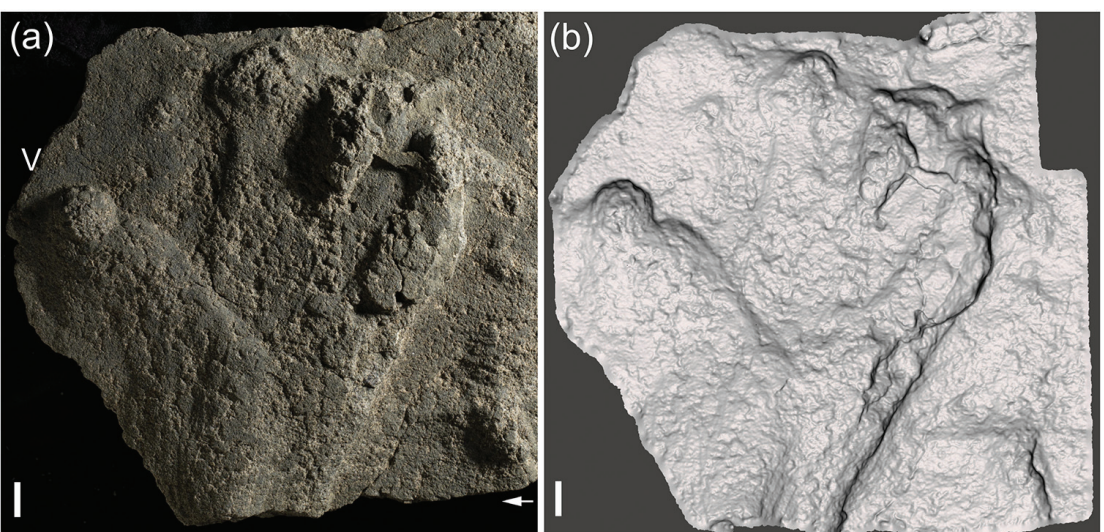

(d)

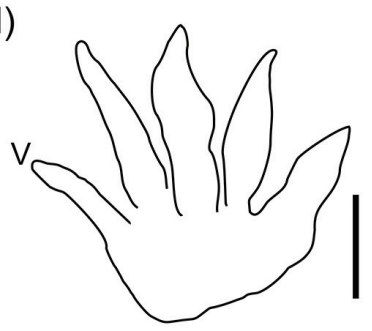

(e)

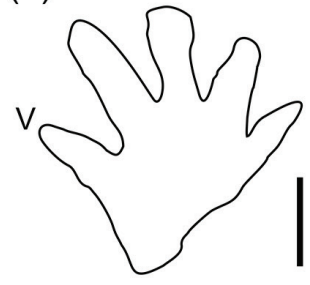

(c)

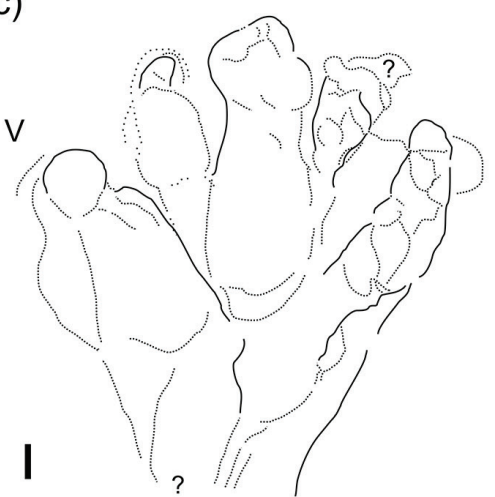

(f)

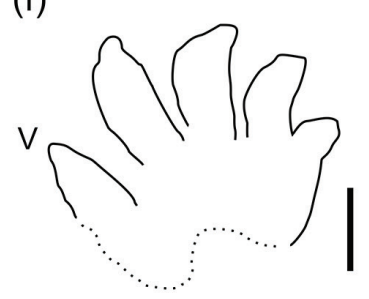

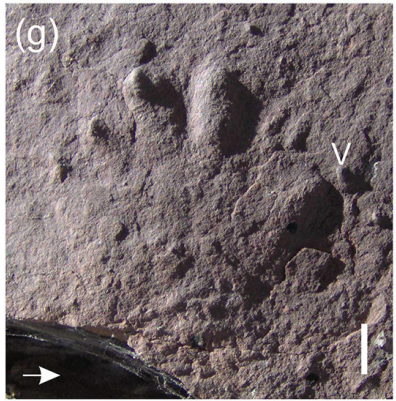

Fig 2 (a-c) Footprint of cf. Procolophonichnium isp., Triassic, northern Victoria Land, Antarctica: (a) photograph, arrow indicates direction of light; (b) image from laser scanner; (c) simple interpretative drawing. (d-f) Simplified drawings of Procolophonichnium specimens from other locations: (d) Procolophonichnium nopcsai (Kuhn, 1963), Lower Triassic near Middelburg, Karoo Basin, South Africa; (e) Procolophonichnium winterswijkense (Demathieu \& Oosterink, 1983), Lower-Middle Triassic (Olenekian-Anisian), Buntsandstein and Muschelkalk of the Germanic Basin; (f) Procolophonichnium polonicum (Ptaszyński 2000), Lower Triassic, Wióry, Holy Cross Mountains, Poland); (g) cf. Procolophonichnium isp. (unpublished specimen), Lower Triassic, Wióry, Holy Cross Mountains, Poland. The digit V imprint is indicated with the letter V. Scale bars are $1 \mathrm{~cm}$ long.

Resources, Hannover. Additional casts, photographs and 3D-scans are housed there and also in the GEOSKOP museum in Thallichtenberg, Germany.

\section{Results and discussion}

Ichnogenus Procolophonichnium Nopcsa, 1923

cf. Procolophonichnium isp.

Fig. 2a, b, c

Material. Poorly preserved, isolated left pes imprint; specimen preserved as natural cast.

Description. Medium-sized pentadactyl pes imprint, characterized by a long digit $\mathrm{V}$ imprint situated close to the digit group I-IV. Digit group I-IV short and wide. Tip of digit $\mathrm{V}$ on the level of half the length of digit IV and tip of digit I. Digits moderately broad and curved outwards, increasing in length from I to V. Digit V positioned posterolaterally to digit group I-IV. Digit IV subequal in length with digit III.

Remarks and comparisons. This specimen should be included in the ichnogenus Procolophonichnium because of the presence of a long digit V imprint situated close to the digit group I-IV. Procolophonichnium ichnites are relatively rare components of Late Permian/Early Triassic through Late Triassic ichnofaunas (see Klein \& Niedźwiedzki 2012; Klein et al. 2015). Procolophonichnium is well-known from Lower-Middle Triassic strata in central Europe, especially from the Buntsandstein and some marginal marine Muschelkalk deposits in the Netherlands and Germany (Haubold 1971a, b; Demathieu \& Müller 1978; Demathieu \& Oosterink 1983, 1988). In recent years, several new species of Procolophonichnium have been found in the Lower, Middle and Upper Triassic of Europe (Ptaszyński 2000; Diedrich 2002a, b; Klein et al. 2015). Almost all of these species are characterized by relatively small sizes (Fig. $2 \mathrm{~d}, \mathrm{e}, \mathrm{f}$ ) and by a long digit $\mathrm{V}$, which is positioned posterolaterally to digit group I-IV (Klein et al. 2015). There are, however, exceptions, and some findings from the upper Lower Triassic (Olenekian) of Poland (Fig. 2g; for more about locality, see Ptaszyński 2000; Klein \& Niedźwiedzki 2012) indicate that Procolophonichnium can also be represented by ichnites of medium size (ongoing study). The specimen 
from Antarctica represents one of the largest known ichnites of this ichnogenus.

Procolophonichnium tracks and trackways were originally attributed to procolophonids (Seeley 1904, 1905; Nopcsa 1923; Haubold 1971a, b; Baird 1986), "Cotylosauria" and turtles (Kuhn 1958, 1963), and/or captorhinids (Haubold 1984). More recent interpretations consider "primitive amniotes" (Klein \& Lucas 2010) or procolophonids and therapsids (Klein et al. 2011; Klein et al. 2015) as track-maker candidates.

The morphology of the Helliwell Hill specimen differs clearly from the three previously described types of trackways from the upper Fremouw Formation of the Queen Alexandra Range, both in size and morphology (see figure 3 in Macdonald et al. 1991). The Helliwell Hill specimen further highlights the largely untapped potential of Beacon Supergroup rocks of northern Victoria Land for the study of the vertebrates that inhabited Antarctica in the Mesozoic.

\section{Acknowledgements}

We are thankful for the logistic support by the Federal Institute for Geosciences and Natural Resources (Bundesanstalt für Geowissenschaften und Rohstoffe, Hannover) and are grateful for the invitation to join the GANOVEX XI expedition. Many thanks also to the staff of the Italian Mario Zucchelli Station for supporting us in the field and at the base; the pilots and engineers of Helicopters New Zealand; the DC-3 Basler and Twin Otter crews of Kenn Borek, Canada; and the master and crew of RV Italica. We are grateful for the help and support of our mountain guides, Maurice Conway and Mike Aitkinson. We thank Sebastian Voigt and Lorenzo Marchetti (Urweltmuseum GEOSKOP, Thallichtenberg) and Hendrik Klein (Saurierwelt Paläontologisches Museum, Neumarkt) for critical discussions on an earlier draft of the manuscript. Sebastian Voigt and Lorenzo Marchetti provided laser scanner images. Daniela Kalthoff (Swedish Museum of Natural History, Stockholm) provided Fig. 1. We are also very grateful to reviewers, Grzegorz Niedźwiedzki and Giuseppe Santi, for their constructive criticism of the submitted typescript.

\section{Disclosure statement}

No potential conflict of interest was reported by the authors.

\section{Funding}

TM thanks the Swedish Polar Research Secretariat for providing polar equipment. BB thanks the Swedish Research Council (VR grant no. 2012-5323) and the
German Science Foundation (DFG grant no. BO3131/1-1) for financial support and the Alfred Wegener Institute's Helmholtz Centre for Polar and Marine Research for providing polar equipment. LC thanks the Italian National Antarctic Research Program (PNRA) and project PNRA_2013/AZ2.02 for financial support.

\section{References}

Baird D. 1986. Some upper Triassic reptiles, footprints, and an amphibian from New Jersey. Mosasaur 3, 125-153.

Barrett P.J., Baillie R.J. \& Colbert E.H. 1968. Triassic amphibian from Antarctica. Science 161, 460-462, https://doi. org/10.1126/science.161.3840.460.

Bomfleur B. \& Mörs T. 2016. New plant-fossil sites in the Victoria Group (Permian-Jurassic) in the far north of Victoria Land, East Antarctica. In: Boletín de la Asociación Latinoamericana de Paleobotánica y Palinología 16. XIV IPC e $X$ IOPC. Palaeobotany and palyonology: towards new frontiers. Salvador (Brazil) 2016. P. 220. Salvador, Brazil: Asociación Latninoamericana de Paleobotánica y Palinología.

Bomfleur B., Mörs T., Oh C., Park T.-Y., Woo J., Crispini L. \& Läufer A. 2018. New Permian-Jurassic deposits in the far north of Victoria Land, East Antarctica. In: Polar2018. Where the poles come together. Abstract proceedings. Open Science Conference. 19-23 June 2018. Davos, Switzerland. P. 2108. Davos: Scientific Committee on Antarctic Research and International Arctic Science Committee.

Covacevich V. \& Rich P.V. 1982. New bird ichnites from Fildes Peninsula, King George Island, West Antarctica. International Union of Geological Sciences, Series B 4, 245-254.

Demathieu G. \& Müller E. 1978. Fährten von Kleinreptilien im Mittleren Buntsandstein bei Britten (Saarland). (Tracks of small reptiles in the Middle Buntsandstein near Britten [Saarland].) Jahresberichte und Mitteilungen des Oberrheinischen Geologischen Vereins 60, 155-165, https://doi. org/10.1127/jmogv/60/1978/155.

Demathieu G. \& Oosterink H.W. 1983. Die WirbeltierIchnofauna aus dem Unteren Muschelkalk von Winterswijk (die Reptilfährten aus der Mitteltrias der Niederlande). (The vertebrate ichnofauna from the Lower Muschelkalk of Winterswijk [reptilian tracks from the Middle Triassic of the Netherlands].) Staringia 7, 1-51.

Demathieu G. \& Oosterink H.W. 1988. New discoveries of ichnofossils from the Middle Triassic of Winterswijk (the Netherlands). Geologie en Mijnbouw 67(1), 3-17.

Diedrich C. 2002a. Wirbeltierfährten aus dem Unteren Muschelkalk (Mitteltrias) von Thüringen (SE-Deutschland). (Vertebrate tracks from the Lower Muschelkalk [Middle Triassic] of Thuringia [south-east Germany].) Neues Jahrbuch für Geologie und Paläontologie, Monatshefte 2, 75-91.

Diedrich C. 2002b. Die Wirbeltierfundstelle Borgholzhausen (Teutoburger Wald, NW-Deutschland) aus der OolithZone (Unterer Muschelkalk, Mitteltrias). (The vertebrate site Borgholzhausen [Teutoburg Forest, north-west Germany] from the Oolith Zone [Lower Muschelkalk, Middle Triassic].) Paläontologische Zeitschrift 76(1), 35-56. 
Hammer W.R., Collinson J.W., Askin R.A. \& Hickerson W.J. 2004. The first upper Triassic vertebrate locality in Antarctica. Gondwana Research 7, 199-204, https://doi. org/10.1016/S1342-937X(05)70319-1.

Haubold H. 1971a. Die Tetrapodenfährten des Buntsandsteins. (The tetrapod tracks of the Buntsandstein.) Paläontologische Abhandlungen A IV, 395-548.

Haubold H. 1971b. Ichnia Amphibiorum et Reptiliorum fossilium. (Tracks of fossil amphibians and reptiles.) Encyclopedia of Paleoherpetology 18, 1-124.

Haubold H. 1984. Saurierfährten. (Saurian tracks.) 2nd edn. Wittenberg, Germany: A. Ziemsen Verlag.

Klein H. \& Lucas S.G. 2010. Review of the tetrapod ichnofauna of the Moenkopi formation/group (early-middle Triassic) of the American Southwest. New Mexico Museum of Natural History and Science Bulletin 50, 1-67.

Klein H., Lucas S.G. \& Voigt S. 2015. Revision of the ?Permian-Triassic tetrapod ichnogenus Procolophonichnium Nopcsa 1923 with description of the new ichnospecies P. lockleyi. Ichnos 22, 155-176, https://doi.org/10.1080/10 420940.2015 .1063490$.

Klein H. \& Niedźwiedzki G. 2012. Revision of the lower Triassic tetrapod ichnofauna from Wióry, Holy Cross Mountains, Poland. New Mexico Museum of Natural History and Science Bulletin 56, 1-62.

Klein H., Voigt S., Saber H., Schneider J.W., Hminna A., Fischer J., Lagnaoui A. \& Brosig, A. 2011 . First occurrence of a middle Triassic tetrapod ichnofauna from the Argana Basin (western High Atlas, Morocco). Palaeogeography, Palaeoclimatology, Palaeoecology 307, 218-231, https://doi. org/10.1016/j.palaeo.2011.05.021.

Kuhn O. 1958. Die Fährten der vorzeitlichen Amphibien und Reptilien. (The tracks of prehistoric amphibians and reptiles.) Bamberg, Germany: Meisenbach.

Kuhn O. 1963. Ichnia tetrapodorum. Fossilium catalogus: animalia. (Tetrapod trace fossils. Fossil catalogue: animals.) Vol. 1. Deventer, Netherlands: Ysel Press.

Macdonald D.I.M., Isbell J.L. \& Hammer W.R. 1991. Vertebrate trackways from the Triassic Fremouw formation, Queen
Alexandra Range, Antarctica. Antarctic Journal of the United States 26, 20-21.

Mansilla H.G., De Valais S., Stinnesbeck W., Varela N.A. \& Leppe M.A. 2012. New Avian tracks from the lower to middle Eocene at Fossil Hill, King George Island, Antarctica. Antarctic Science 24, 500-506, https://doi.org/10.1017/ S0954102012000260.

Miller F., Hasiotis S., Babcock L., Isbell J. \& Collinson J. 2001. Tetrapod and large burrows of uncertain origin in Triassic high paleolatitude floodplain deposits, Antarctica. Palaios 6, 218-232.

Nopcsa F. 1923. Die Familien der Reptilien. Fortschritte der Geologie und Paläontologie. (The families of reptiles. Advances in geology and paleontology.) Vol. 2. Berlin: Verlag Gebrüder Borntraeger.

Ptaszyński T. 2000. Lower Triassic vertebrate footprints from Wióry, Holy Cross Mountains, Poland. Acta Palaeontologica Polonica 45, 151-194.

Seeley H.G. 1904. Footprints of small fossil reptiles from the Karroo rocks of Cape Colony. Annals and Magazine of Natural History London 14, 287-289.

Seeley H.G. 1905. On footprints of small fossil reptiles from the Upper Karroo rocks of Cape Colony. Report of the British Association for the Advancement of Science 74, 549-550.

Sidor C.A., Miller M.F. \& Isbell J.F. 2008. Tetrapod burrows from the Triassic of Antarctica. Journal of Vertebrate Paleontology 28, 277-284.

Smith N.D. 2013. New directions in vertebrate paleontological research in the Transantarctic Mountains, Antarctica. Palaios 28, 680-682.

Smith N.D., Crandall J.R., Hellert S.M., Hammer W.R. \& Makovicky P.J. 2011 . Anatomy and affinities of large archosauromorphs from the lower Fremouw Formation (early Triassic) of Antarctica. Journal of Vertebrate Paleontology 31, 784-797.

Stilwell J.D. \& Long J.A. 2011. Frozen in time: prehistoric life in Antarctica. Collingwood, Australia: CSIRO Publishing. 